\title{
Correction to: Sources of variability in SERS spectra of bacteria: comprehensive analysis of interactions between selected bacteria and plasmonic nanostructures
}

\author{
Evelin Witkowska ${ }^{1} \cdot$ Krzysztof Niciński $^{1} \cdot$ Dorota Korsak $^{2} \cdot$ Tomasz Szymborski $^{1} \cdot$ Agnieszka Kamińska $^{1}$
}

Published online: 3 June 2019

(C) Springer-Verlag GmbH Germany, part of Springer Nature 2019

\section{Correction to: Anal Bioanal Chem} https://doi.org/10.1007/s00216-019-01609-4

The authors would like to call the reader's attention to the fact that unfortunately following information was missing in the original article:

"Evelin Witkowska is supported by the Foundation of Polish Science (FNP)."

Publisher's note Springer Nature remains neutral with regard to jurisdictional claims in published maps and institutional affiliations.

The online version of the original article can be found at https://doi.org/ 10.1007/s00216-019-01609-4

Evelin Witkowska ewitkowska@ichf.edu.pl

$\triangle$ Agnieszka Kamińska akamin@ichf.edu.pl

1 Institute of Physical Chemistry, Polish Academy of Sciences, Kasprzaka 44/52, 01-224 Warsaw, Poland

2 Faculty of Biology, Institute of Microbiology, Department of Applied Microbiology, University of Warsaw, Miecznikowa 1,

02-096 Warsaw, Poland 